\title{
Beijing's Orphans? New Chinese Investors in Papua New Guinea \\ Graeme Smith
}

\begin{abstract}
This paper will explore the perspectives and narratives developed by three different sets of Chinese investors in Papua New Guinea (PNG): investors in the retail, mining and construction sectors. It is estimated that 90 percent of new Chinese private investors in the PNG retail sector hail from Fuqing, a coastal community in Fujian Province with a long history of transnational migration. Larger state-owned mining ventures and construction companies draw on a more disparate workforce, even though they are headquartered in Beijing. All three sets of investors face different degrees of stigmatization from their competitors, the media and different Chinese and local actors. Based on interviews with Chinese investors in PNG and China, and drawing on Chinese scholarly studies, this paper will explore the interaction of these three groups of investors with Chinese state and non-state actors, and evaluate how this shapes the process of "localization." The paper will examine how relations with state and non-state actors in PNG are evolving over time, as both groups find ways to "get things done" in a country where mainland Chinese investors have a short history of engagement.
\end{abstract}

KEYWORDS: State-owned enterprises, investment, China, Papua New Guinea, stigmatization, localization

DOI: http:/ /dx.doi.org/10.5509/2013862327

\section{Introduction}

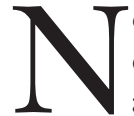

ew Chinese investors in Papua New Guinea fit Erving Goffman's definition of a group that is "disqualified from full social acceptance" and suffers from stigma, or "a special discrepancy between virtual and actual social identity." In terms of the broader theme of this special issue, the concepts of "stigmatization" and the "established-outsider differential" 2 are useful in exploring how different groups of Chinese

\footnotetext{
Erving Goffman, Stigma: Notes on the Management of Spoiled Identity (Englewood Cliffs, NJ: Prentice-Hall, 1963), 3.

2 Norbert Elias and John L. Scotson, The Established and the Outsiders: A Sociological Enquiry into Community Problems (London: Sage, 1994:1965).
} 
investors interact with each other. ${ }^{3}$ Furthermore, these tensions can lead us to explore how these new investors interact with the established norms of how business ought to be done in the host country. Investors in the retail and wholesale sector find themselves measured (and measuring themselves) against "old" Chinese merchants; the Ramu Nickel project faces comparison to Western mining companies with longer histories in the extractive sector of PNG; and construction companies face a regulatory environment that is based upon Australian standards.

For many observers, it is hoped that these tensions will drive new Chinese investors to adopt the norms of established investors, and learn to "play by the rules of the road" 4 followed by the established investors, and "internalize internationally mainstream business models." ${ }^{5}$ Leaving aside the question of whether established investors actually obey such rules, which in the case of the extractive industry sector is doubtful, ${ }^{6}$ this article will argue that such linear outcomes are unlikely, but these tensions do play a crucial role in shaping how new Chinese investors in PNG "get things done." ${ }^{77}$ A more useful framework to apply is Amitav Acharya's concept of localization, studying how different sets of Chinese actors "build congruence between transnational norms (including norms previously institutionalized in a region) and local beliefs and practices." ${ }^{8}$

Examining different groups of state-owned and private Chinese investorsin the retail, mining and construction sectors-gives us a more complete picture of how different parts of the Chinese state become "re-territorialized" beyond China's borders. ${ }^{9}$ How do actors in these three different economic sectors negotiate and make sense of state and society in PNG, and what effect does external pressure have on their business practices? There are limitations to a case study approach: the characteristics of Chinese retail, mining and construction investors in PNG cannot be taken as representative of Chinese investors in the developing world or the Pacific region. In the retail sector, the Fuqing business community brings specific historical and cultural factors that may differ from other diasporas in the Pacific and beyond. In the mining

\footnotetext{
Ayse Zarakol, After Defeat: How the East Learned to Live with the West (Cambridge: Cambridge University Press, 2011).

BBC News, "US President asks China to follow 'same rules' in trade," 15 February 2012, available online at http:/ /www.bbc.co.uk/news/business-17036837, last accessed 18 February 2012.

$5 \quad$ Ruben Gonzalez-Vicente, "The Internationalization of the Chinese State," Political Geography 30 (2011): 405 .

6 Multinational corporations in PNG's mining sector have an unenviable history of environmental and social impacts. See Chris Ballard and Glenn Banks, "Resource Wars: The Anthropology of Mining," Annual Review of Anthropology 32 (2003): 287-313.

7 Scott Kennedy, "The Mandarin Learning Curve: How China Is Reshaping Global Governance," paper presented at the China Social Science Workshop, Stanford University, 13 May 2010.

Amitav Acharya, "How Ideas Spread: Whose Norms Matter? Norm Localization and Institutional Change in Asian Regionalism," International Organization 58, no. 2 (2004): 241.

$9 \quad$ Gonzalez-Vicente, "Internationalization of the Chinese State," 403.
} 
sector, there is much about the largest Chinese investment, the Ramu Nickel project, that is specific to the project management company, China Metallurgical Corporation (MCC); it cannot stand as a proxy for all large Chinese state-owned mining companies, each of which will have their own enterprise cultures, based upon their history and position within the Chinese political system and their experiences in other countries. Similar caveats apply in the construction industry, where the number of Chinese firms has increased rapidly since 2007. By 2012, 13 of the 20 largest Chinese companies registered in PNG were construction contractors, ${ }^{10}$ ranging from subsidiaries of large state-owned companies to loosely affiliated semi-private firms. However, to move beyond accepting that "China" is not a monolithic actor and that there is no such thing as the "Beijing Consensus," 11 and to move towards understanding what "rules of the game" Chinese actors are adopting as they do business in a challenging environment such as PNG, such microanalyses are indispensible. Accurate statistics on trade flows, the amount of Chinese overseas direct investment (ODI) into PNG, or even the number of Chinese nationals in PNG, are not available. ${ }^{12}$

High-profile Chinese investments backed by state-owned enterprises, such as the Ramu Nickel project, tend to attract more attention than the activities of small and medium-sized businesses. Larger, state-backed investments appear on the radar of international mergers and acquisitions activity and feed into concerns about China's resource diplomacy. However, researchers at PNG's Investment Promotion Authority, the agency charged with registering and monitoring foreign businesses, estimate that investment in the retail and wholesale sector accounts for nearly half of the Chinese outbound direct investment (ODI) flowing into the country, far more than investment in the resources sector, which (at least at present) is largely confined to the Ramu Nickel project. ${ }^{13}$ Despite representing the largest share of Chinese investment in PNG, it is rarely mentioned as a significant impact on the regional economy, even in nuanced overviews of China's engagement with the Pacific. ${ }^{14}$

10 Chinese Embassy in PNG, "Baxin zhuyao zhongzi qiye" [The main Chinese enterprises in PNG], 20 September 2012, available online at http://pg.mofcom.gov.cn/aarticle/catalog/ zgqy/201209/20120908349512.html?4133301016=354492889, last accessed 23 October 2012.

11 Scott Kennedy, "The Myth of the Beijing Consensus," Journal of Contemporary China 19, no. 65 (2010): 461-77.

12 See also Filer, this volume. Even estimating the number of Papua New Guineans is a near impossible exercise, given the rugged terrain, sparse population and limited reach of the PNG state. See Post Courier, "2010 National Census is a failure: O’Neill," 18 January 2012, available online at http://www.postcourier.com.pg/20120118/news05.htm, last accessed 19 February 2012.

13 IPA, interview by author, Port Moresby, 1 November 2011.

14 Matthew Hill, “Chessboard or 'Political Bazaar'? Revisiting Beijing, Canberra and Wellington's Engagement with the South Pacific," Security Challenges 6, no. 3 (2010): 41-58; Yang Jian, The Pacific Islands in China's Grand Strategy: Small States, Big Games (New York: Palgrave Macmillan, 2011). 
Based on interviews with Chinese small business owners in Madang, Port Moresby, Goroka in PNG, and Fujian Province in China, the next section will explore the development of the business practices of Chinese retail investors in PNG and how they interact with the Chinese and Papua New Guinean states. It will examine how these practices, and their capacity to "localize" and find congruence with local norms, are shaped by the politics of two decades of interaction with the old Chinese, PNG nationals, their home community and the Chinese and PNG states. The following sections will then examine how new Chinese entrants in the PNG mining and construction sector, with an even shorter history of engagement, adapt and localize in the context of an unfamiliar business environment. While successful integration as newcomers requires the capacity to be a "normtaker," larger construction and mining companies bring their own histories as "norm-makers" in the Chinese domestic economy. ${ }^{15}$ Is it possible for their enterprise cultures to adapt to an environment where norms surrounding land ownership, the roles of civil society and the media, management and negotiation practices are starkly different from the Chinese domestic context? How does this affect Chinese firms' capacity to find congruence with local business practices?

\section{The Retail Trade}

One of my first encounters with Malaysian Chinese loggers in PNG was in a small Madang restaurant, run by a family from Fujian Province. At the time, it was yet to obtain the permits to allow it to open, but it was still serving food to close friends. The loggers stood out, not just because of the M-16 that their bodyguard cradled between his knees, like a man contemplating suicide, but through their confidence. True to cliché, if not reality, ${ }^{16}$ the group worked for the Malaysian logging company Rimbunan Hijau, and had just returned from Gabon, which they pronounced to be much safer than PNG. "We don't need an armed guard there," they declared. In between fried dumplings, the loggers asserted that although we were enjoying an amicable meal, I must hate them, because all Westerners hated them. They didn't care either way.

This was in contrast to the uncertainty and anxiety that were the constant companions of the family who ran what was to become Madang's most notorious "grog shop." Within the new Chinese community, they enjoyed great esteem, and were the driving force behind the establishment of a business association. Yet they, and all new business migrants from Fuqing I interviewed, were painfully aware of their status as "outsiders." In the eyes

\footnotetext{
15 Jeffrey T. Checkel, "Norms, Institutions, and National Identity in Contemporary Europe," International Studies Quarterly 43 (1999): 83-114.

16 Filer, "Asian Investment."
} 
of many locals, the established Chinese community in PNG, and the Chinese state itself, these businesspeople were reduced "from a whole or usual person to a tainted, discounted one." ${ }^{17}$ Shorn of respectability, despised in almost equal measure by Chinese and local actors alike, they offered a uniquely honest perspective on investing beyond China's borders.

The Chinese investment wave in PNG's retail and wholesale sector, which began during the early 1990s, has attracted attention from local media outlets, and has been noted in two scholarly accounts. ${ }^{18}$ Media accounts usually equate the new Chinese business community in PNG with organized crime. ${ }^{19}$ Given this rather unsavory reputation, it is unsurprising that the voices of the new Chinese themselves are absent from such accounts. One wire correspondent, based in Port Moresby, admitted that he was too scared to interview these new migrants because they were involved with "triads," which he frequently mentioned in his dispatches. How he substantiated these assertions without talking to the new Chinese community was unclear. In accounts within PNG and beyond, new Chinese are often stigmatized as failing to live up to the norms established by the old Chinese communities in terms of allegiance to the host nation and willingness to adopt local customs.

In PNG, the source of this investment is largely a single community. Leaders of Chinese community groups in Port Moresby estimate that 90 percent of new Chinese investors in the retail trade hail from Fuqing, a coastal town in Fujian Province with a history of business migration, notably to Japan, but also to the United States, Australia, Canada, South Africa and Argentina. Moreover, most of the new migrants to PNG are from a handful of villages outside the town, centred on the village of Youyi Cun (Friendship Village). Although official Chinese migration statistics are meaningless, an expert on the Fujian diaspora estimates that two million migrants have left the province in the past two decades. Migrants from Fujian make up 29 percent of mainland Chinese migrants worldwide, ${ }^{20}$ although the province accounts for less than 3 percent of the overall Chinese population.

There is evidence that Chinese officials are involved in supporting outward migration, because of its potential to boost local GDP and revenue receipts, both crucial to their prospects of promotion. ${ }^{21}$ In Africa, Chinese provincial

17 Goffman, Stigma, 3.

18 James Chin, "Contemporary Chinese Community in Papua New Guinea: Old Money Versus New Migrants," Chinese Southern Diaspora Studies 2 (2008): 117-26; Tetsu Ichikawa, "Chinese in Papua New Guinea: Strategic Practices in Sojourning," Journal of Chinese Overseas 2, no. 1 (2006): 111-32.

19 Post Courier, "Aliens in PNG," 13 January 2012; Julian Bore, "Chinese arrested for murder attempt on PNG businessman: Police believe Asian organized crime behind shooting," The National, 4 January 2010.

20 Guo Yucong, "Fujian sheng guoji yimin de yimin wangluo fenxi: Jianping yimin wangluo lilun" [Networks for International Emigration in Fujian Province and Migration Network Theory], Xiamen daxue xuebao [Journal of Xiamen University], no. 6 (2009): 114.

21 Graeme Smith, "The Hollow State: Rural Governance in China," China Quarterly 203 (2010): 601-18. 
governments take responsibility for dispatching revolving Chinese medical teams to specific countries. ${ }^{22}$ At the next level down, local governments in Fujian provide skills training to migrants bound for countries such as Japan..$^{23}$ While Fuqing has a tradition of international migration, scholar Frank Pieke has observed a new wave of migration from non-traditional regions such as Shandong, Yunnan and the Northeast, observing "the growth of such new overseas Chinese areas does not happen spontaneously, but is predicated on the endorsement by, and active support from, the local government that incorporates international migration in its development and modernisation strategy." ${ }^{24}$ Do migrants bound for the Pacific benefit from state-backed interventions, as some have suggested ${ }^{25}$ My interviews suggest that investment migration to PNG has grown organically, with little involvement from the Chinese state. In 1991, one Fuqing migrant was sent by a Fuzhou-based labour contracting company to work in Port Moresby on a construction project. The venture didn't go to plan; he stayed on, and remains in the capital to this day.

One barrier to new Chinese migrants adopting local business norms is the difficulty in forming connections with the existing Chinese community. ${ }^{26}$ Before examining the interactions between the established Chinese business community and the "outsiders," one should not draw too sharp a divide: there are more than two Chinese business communities. There have been three waves of Chinese migration in PNG, with the "old" Chinese migrants from a variety of areas in southern China, pushed by famine and war from the late nineteenth century onwards, followed by Malaysian Chinese from the 1960s. ${ }^{27}$ Many of these Malaysian Chinese migrants left Fuqing during an earlier wave of migration, induced by the Japanese invasion and the ongoing civil war between the Nationalists and the Communists in the 1930s and 1940s..$^{28}$ The main factor that leads to migration networks being closed,

22 Elizabeth Hsu, "Zanzibar and Its Chinese Communities,” Population, Space and Place 13 (2007), 115. Similarly, provincial agricultural experts are dispatched to specific African countries, though not necessarily the same ones as the medical teams. I am grateful to an anonymous reviewer for pointing this out.

23 Zhuang Guotu, "Jin 30 nian lai de Zhongguo haiwai yimin: Yi Fuzhou yimin wei li” [30 Years of Chinese Immigration: Fujian as a Case Study], Shijie minzu [World Ethno-National Studies] no. 3 (2006): 38-46.

24 Frank N. Pieke, "Editorial Introduction: Community and Identity in the New Chinese Migration Order," Population, Space and Place 13 (2007): 91.

25 Ron G. Crocombe, Asia in the Pacific Islands: Replacing the West (Suva: University of the South Pacific, 2007).

26 Wen-Chin Chang, "The Interstitial Subjectivities of the Yunnanese Chinese in Thailand," The Asia-Pacific Journal of Anthropology 9, no. 2 (2008): 97-122.

27 Bill Willmott, "The Overseas Chinese Experience in the Pacific," in China in Oceania: Shaping the Pacific? eds. Terence Wesley-Smith and Edgar A. Porter (London: Berghahn Books, 2010), 93-103; David Y.H. Wu, The Chinese in Papua New Guinea: 1880-1980 (Hong Kong: The Chinese University Press, 1982).

$28 \mathrm{Xu}$ Jinding, "Jin xiandai Fuqing qiaoxiang liang ci yimin langchao" [Inquiry into Two Emigration Tides from Fuqing as the Hometown of Overseas Chinese], Huaqiao daxue xuebao [Huaqiao University Journal] no. 4 (2002): 69-74. 
language,$^{29}$ is shared between many of the members of the "new" and Malaysian Chinese communities. It is more common for the new migrants from mainland China to share business links with Malaysian Chinese investors than with the previous generation of "old" Chinese, who are descended from migrants who arrived as long ago as the nineteen century, and often only speak English and Tok Pisin.

In the broader Pacific context, there is evidence that newcomers are stigmatized and excluded by established Chinese business communities. There are accounts of the businesses of new Chinese from Guangdong being targeted for burning during the Solomon Islands riots of 2006, while old Chinese businesses, which enjoyed long-standing relationships with the local community, were left untouched. ${ }^{30}$ Similar conditions appear to prevail in PNG. Monash University scholar James Chin has contrasted the benevolent old Chinese community with the "aggressive" newcomers whose "idea is to make as much money as possible before moving on to countries like Australia and New Zealand." ${ }^{31}$

In interviews with old Chinese business owners, their contempt for newcomers is often unrestrained. One wholesaler declared them "a bunch of thieves, all from the same family... We've had enough; our time is up. We can't do business in the new [corrupt] way." He was, however, gradually selling off his assets to the new Chinese, because "the nationals don't have the money to buy the shops, and they can't run a business, just like the government can't run the country." ${ }^{2}$ Other established businessmen claimed to play a mentoring role for newcomers, urging them to be seen to contribute more to PNG by sponsoring sporting teams and community groups, but were not confident that many Fuqing businesspeople listened to their advice about conducting business in PNG. ${ }^{33}$

Many new Chinese see tensions between the old and the new communities as arising from the realities of business. The Fuqing Chinese business community has been in PNG for less than two decades. Contrary to Dr Chin's claims, five years is too short a time to accumulate a fortune in the PNG retail sector, and businesses operate on thin margins. Typically, they work in the shop of a relative before opening up their own business, which they purchase from within their circle. They rarely own stores outright, face high rents from

29 Gracia Liu-Farrer, "The Burden of Social Capital: Visa Overstaying among Fujian Chinese Students in Japan,” Social Science Japan Journal 11, no. 2 (2008): 241-57.

30 Clive Moore, "No More Walkabout Long Chinatown: Asian Involvement in the Economic and Political Process," in Politics and State Building in the Solomon Islands, eds. Sinclair Dinnen and Stewart Firth (Canberra: Asia Pacific Press, 2008), 64-95; Graeme Smith, "Chinese Reactions to Anti-Asian Riots in the Pacific," Journal of Pacific History 74, no. 1 (2012): 109-25.

31 Radio Australia, "Chinese shops issue not about race says business leader," 18 April 2011, available online at http://www.radioaustralia.net.au/pacbeat/stories/201104/s3194052.htm, last accessed 7 February 2012.

32 Interview by author, Madang, 28 October 2009.

33 Interview by author, Goroka, Eastern Highlands Province, 9 November 2011. 
local landlords, often go into debt, face high interest repayments, and find themselves uninsured. Unable to pay for goods, they draw the chagrin of wholesalers, who tend to be old Chinese. The reaction of many Fuqing merchants to stigmatization is resistance, and a belief that they will eventually drive the old Chinese out of PNG: ${ }^{34}$

These [old] Chinese, when they see Mainland Chinese, they look down on us (kan bu da qi); on our low level of education, our poor English. Our English is poor, that's true, and we work like dogs. Their lives are different, plenty of leisure, so when we work like that, it influences their business. They'll open at eight o'clock, close at five, and won't open in the evening; we'll be open at seven, and stay open until seven at night. There's contempt, but also fear... We're Chinese, just like them, but they think we're garbage: working all hours, living in terrible conditions.

Among some new Chinese, the reaction to stigmatization by the old Chinese business community is to justify their refusal to adopt their norms, and to delight when their "betters" fall victim to their fraudulent practices. This businessman, and many others, was "insulated by his alienation, protected by identity beliefs of his own, he feels that he is a fully-fledged normal human being, and that we are ones who are not quite human. He bears a stigma but does not seem to be impressed or repentant about doing so." ${ }^{55}$ Rather than stigmatization leading to socialization into established business practices, or a "civilizing process," it may lead to the opposite.

A more common reaction, however, was to isolate community members who were giving them a "bad name." In Goffman's terms, there was "a tendency to stratify his 'own' according to the degree to which their stigma is apparent and obtrusive. He can then take up in regard to those who are more evidently stigmatized than himself the attitudes the normals take to him." ${ }^{36}$ In their interactions with the PNG state, they are conscious of their second-class status, especially relative to other Chinese. One interviewee recounted the shooting of Malaysian-born, Port Moresby-based businessman Jason Tan by two thugs, one from Fuqing, the other from neighbouring Dongling, in January 2010. ${ }^{37}$ "After they were caught, it affected everyone. People would say that the worst sorts of people are here; Chinese killers have come into our country. Our reputation was destroyed. Wherever Chinese people go, particularly Fuqingese, our name is worse than pig shit. There's too much illegal migration, and there are too many new arrivals." ${ }^{38}$ This

34 Interview by author, Bogia, Madang Province, 27 June 2010.

35 Goffman, Stigma, 6.

36 Goffman, Stigma, 107.

37 Rowan Callick, "Triads Arrested After PNG Shooting," The Australian, 5 January 2010. Two years later, the bungling would-be killers, who were bested by Tan's bodyguard and the PNG police, are yet to be sentenced. Interviews suggest that rather than being "Triad assassins," they were amateurs hired by one of Mr Tan's relatives. Disorganized, rather than organized crime.

38 Interview by author, Fuqing, July 2010. 
status has consequences. Police are reluctant to investigate robberies at their stores, and crackdowns on "aliens" are more violent if the word FUJIAN is found in their passport.

Some businessmen recalled a time when the country was orderly, and Chinese merchants were respected. They blamed recent arrivals for their change in status, and recalled incidents that they blamed for their fall from grace, such as the proliferation of gambling machines in Chinese shops during the early 2000s. While Malaysian Chinese criminals ran the syndicate, it was associated with the new Chinese. As one interviewee asked, in earshot of another merchant who had a "horse racing machine" in his shop, "They were taking money from the poorest people in the community, even children. What sort of person does that?" The accused sheepishly protested that while he repaired the machines, he was just an employee. He never cheated anyone out of money. ${ }^{39}$

Some Chinese government officials, far from supporting business migrants, contribute to their stigmatization. They see them as a source of embarrassment, rather than a sign of China's growing economic and political influence. In 2006, Honiara's Chinatown was burnt to the ground. As the vast majority of new business migrants to the Solomon Islands were from Guangdong Province, the Guangdong Office of Overseas Chinese Affairs sent a team to investigate. Their report blamed the new arrivals for the riot, noting that: ${ }^{40}$

Their quality (suzhi) is low. Most do not understand foreign languages, and have no knowledge of foreign trade. They lack the calm and patience of the previous generation of migrants, often grasping for money with no thought to the consequences, and they are happy to use cash to grease all transactions ... Relevant departments of Guangdong Province should exercise appropriate restraint to prevent the phenomenon of excessive concentration of immigrants from certain areas in certain countries. We support and permit the migrants, but not without conditions. If goods have export quality standards, should migrants not also meet a quality standard? For goods, at the point of export there is a standard; our migrants ought to face such a standard.

Thus, at the provincial level, those who invest in a less developed country are viewed with a patronizing attitude by the agency charged with protecting them.

While some literature in Pacific Studies suggests new Chinese business migrants are supported by the Chinese state,${ }^{41}$ or are a vector for spreading

39 Interview by author, Port Moresby, 5 October 2010.

40 Lü Weixiong, "Cong suoluomen tangren jie bei shao shuo qi" [Discussing the Burning of Solomon Islands' Chinatown], 7 May 2009, available online at http://www.jsqw.com/html/ dv_453110835.aspx, last accessed 7 February 2012.

41 Crocombe, Asia in the Pacific Islands; Paul Buchanan, "Chinese expansion and a new containment policy in South Pacific," Pacific Scoop, 24 February 2012, available online at http:/ / pacific. scoop.co.nz/2012/02/paul-buchanan-china-and-a-new-containment-policy-in-the-south-pacific, last accessed 27 February 2012. 
China's influence ${ }^{42}$ interviews with migrants and Chinese academics indicate the opposite. For entrepreneurs from Fuqing, the central and the local Chinese state are absent from their daily lives. A few longstanding business owners were invited to attend the visit of Vice Premier Li Keqiang to Port Moresby in November 2009, but for the majority, they only visit the embassy when they need to renew their passports. A similar pattern has been observed in Chinese business communities in Africa. ${ }^{43}$

Embassies in the Pacific do play a role in assisting business migrants to set up mutual-aid associations, and encouraging these associations to engage with local communities. However, many complained that the Chinese embassy in Port Moresby did little to protect them from violence and theft. They had modest expectations of what consular services the embassy might provide. A group of shopkeepers in Port Moresby laughed when asked if embassy staff liaised with police in the event of a robbery. "Even when someone gets killed, they're no use. They'll just send out a notice telling you to take extra care, and not to go out." ${ }^{44}$ There is a perception that embassy staffers have little sympathy for Fuqing business owners, viewing it as their lot to be in trouble (ming bu hao). They see no possibility that the Chinese state will intervene. As one explained, "All they can do is host visitors, conduct ceremonies, there's no capacity to do much in PNG. China is still too poor... and besides, this country isn't that important. It was only after Taiwan [tried to] buy their allegiance that they gave it some attention." 45

Nor do they receive support from the local state in Fuqing. One migrant, who had been active in the PNG-China Friendship Association while living in Rabaul and Port Moresby, observed, "The Fujian Overseas Chinese Affairs Office has no eyes for this place [PNG]; they just don't see it. They only see Japan, America, Australia and Canada. They look down on PNG. It only has five million or so people, after all... There are hundreds of thousands of Fuqing migrants in Japan, and if each of them sends back 5000 yuan per month, that's hundreds of millions in remittances. In PNG, there might be over a thousand migrants, and they earn less." ${ }^{26}$

\footnotetext{
42 John Henderson and Benjamin Reilly, "Dragon in Paradise: China's Rising Star in Oceania," The National Interest 72 (2003): 94-104.

43 Jørgen Carling and Heidi Østbø Haugen, "Mixed Fates of a Popular Minority: Chinese Migrants in Cape Verde" in China Returns to Africa: Rising Power and a Continent Embrace, eds. Chris Alden, Daniel Large and Ricardo Soares de Oliveira (New York: Columbia University Press, 2008); Terence McNamee, Greg Mills, Sebabatso Manoeli, Masana Mulaudzi, Stuart Doran and Emma Chen, "Africa in Their Words: A Study of Chinese Traders in South Africa, Lesotho, Botswana, Zambia and Angola" (Johannesburg: The Brenthurst Foundation, 2012).

44 Interview by author, Port Moresby, 4 October 2010.

45 Interview by author, Fuqing, 26 July 2010.

46 Interview by author, Fuqing, 25 July 2010. Private investors in Africa experience similar ambivalence from the local state. See Gu Jing, "China's Private Enterprises in Africa and the Implications for African Development," European Journal of Development Research 21, no. 4 (2009): 579-581.
} 
Their business practices are influenced by the Chinese state and their local community, but not in a supportive manner. Interviewees were aware that once the debt incurred by setting up their business in PNG was paid off, a series of financial challenges faced them in China, arising from the retreat of the local state from service provision, and traditional kinship practices. Specifically, they faced the "three big burdens" of healthcare, education and housing. Large sums are spent on weddings and funerals, and there is an expectation that in the absence of a strong local state (the main source of revenue for village governments is typically renting out ponds for aquaculture), the Fuqing diaspora should provide rural infrastructure. A commemorative plaque for donations to build the main road of Youyi Cun indicates the largest contribution was 50,000 yuan. The number of donors in this village of 6,000 souls exceeded 100 families. Fuqing also has a large Christian population, with a church in nearly every village, built with the funds earned by Fuqing merchants. For the residents of Fuqing, the greatest burden is housing. It is not uncommon for Fuqing residents to spend up to five million yuan on renovations for their five-, six- and seven-storey dwellings. Such mansions are more elaborate than elsewhere in rural China and are essential for children to secure a partner.

These burdens meant their sojourn in PNG would be longer, and made them more willing to take risks, and less willing to seek congruence with local norms. Interviewees saw the odd combination of risk-taking and frugality as innate characteristics of the Fuqing people. As one returned migrant argued, "We're different to people over there. Chinese people, especially Fuqing people, the money you earn goes towards building a house, finding a wife, and erecting tombstones. So, if you earn a hundred kina, you can only spend ten or so kina on your living expenses, and the rest goes towards other things. Your life is tiring and impoverished." Their lot was contrasted to other Chinese; particularly those associated with state-backed resource projects, who were "eating the state's grain."

The negative attitude of the central state towards all things Fuqing reached its apogee after a visit by Jiang Zemin in June 2000 to the United Kingdom coincided with the suffocation of 58 Fujianese illegal migrants in the back of a truck in Dover. ${ }^{47}$ The villages of each of the dead were traced (mainly back to Fuqing), and a ban on obtaining passports was immediately placed on the residents of each village. The ambivalent attitude of many Fujianese towards the central government comes through in this interview: ${ }^{48}$

When it happened, it was the turn of the millennium, and China was boasting about having met the basic needs of society (xiaokang shehui),

47 Paul Kelso, "Search for a new life ended in a cauldron of death," 6 April 2001, available online at http://www.guardian.co.uk/uk/2001/apr/06/immigration.immigrationandpublicservices2, last accessed 19 February 2012.

48 Interview by author, Fuqing, 25 July 2010. 
but then your English countrymen wanted to know, if your life over there is so great, why are people risking their lives to come? Jiang was furious. He got on the phone to customs and told them to crack down on people smuggling. So if two or three people from our village were caught, then no one in the whole village could get a passport. That's what our government is like. One person does something and another one pays for it. In the past, the emperor would issue a decree to punish an entire clan for one person's treason. Now, damn them, it's the whole village. The ban stayed for seven years (2000-2007).

Fujian Province was deliberately left out of state rural investment plans during the Maoist era, due to its proximity to Taiwan, thus the infrastructure investment of the 1970s that formed the basis for China's "economic miracle" was not present in Fujian, leaving migration as the best option. Interviewees confirmed that a culture of migration emerged in their home villages over the course of three decades of continuous migration. Men in these landscarce rural communities see international migration as the only choice for a capable (nenggan) man. Many interviewees indicated they would rather stay in China, but social pressure to migrate was too great.

The attitude of retailers towards the PNG state is also ambivalent. Most believed that it was easier to do business in PNG: fewer rent-seeking officials, lower start-up costs, and more freedom to relocate. But even well-established shopkeepers experienced "relentless, formless pressure" ${ }^{49}$ because of physical insecurity, which is not restricted to the Chinese. A wholesaler from the old Chinese community expressed a common concern that local politicians were blaming the Chinese for PNG's problems, "so that the people don't pick on them." He felt that one day a Mugabe-type leader would emerge, "a strong, charismatic man to bring everyone together in hatred of outsiders. He'll likely be from the Highlands." 50

Many aspects of life in PNG appeal to the merchant community, but crime made it unlikely they would settle, contrary to an earlier assessment. ${ }^{51}$ Shops are surrounded by barbed wire, guarded by dogs and security guards. One shopkeeper said, "You can't walk the streets, you can only drive, you can't even get on a bus. There's nowhere to enjoy yourself. Each shop is like a foreign jail. Every day is work, and on Saturday, we get together and chat. On Sunday you sleep. That's all there is." Concerns about the inability of the state to guarantee their safety are real. Nearly all Fuqing merchants are able to point to a bush-knife scar and recount violent robberies in their stores. These negative experiences encouraged them to idealize a strong state. One merchant, located in a remote part of Madang, said: ${ }^{52}$

Interview by author, Madang town, 15 November 2011.

50 Interview by author, Madang town, 28 October 2009.

51 Ichikawa, "Chinese in Papua New Guinea," 123.

52 Interview by author, Karkar Island, Madang Province, 20 June 2010. 
In this country, your life has no guarantee. During the past ten years, there have been a score of incidents where merchants have been killed during robberies. There's one every year. We are all from the same hometown; we know how dangerous it is here. But you've spent time in China; you know how it is. If something like that happened in China, they would definitely catch the killer, no matter how long you might run, the government will catch you.

When pressed as to why they endured stigmatization by the PNG state, the Chinese state, and the old Chinese community, for many, their hopes lay not with business, but with the prospect of education, and the next generation whose future lay in China or the West, but not in PNG. As one merchant explained, "I don't want my children to do this. This is too hard. I want them to attend a good university in China and find a good job. In a few years we'll have earned enough to return home, and we'll just, I don't know, pass the days ( guo rizi)." ${ }^{.53}$

\section{The Mining Sector}

While some reports suggest that new Chinese retail investors have been drawn in by the Ramu Nickel project, ${ }^{54}$ the wave of migration predates China Metallurgical Corporation's arrival in PNG by over a decade. China Metallurgical Corporation (MCC) management see the Fuqing migrants as damaging to the reputation of other Chinese investors in PNG, and they deride them as being involved in organized crime. At a new township, currently under construction near the refinery site at Basamuk, no new Chinese investors have been invited, even though they dominate the retail trade in Madang. There are no Fuqing merchants at either the mine site or the refinery site. While Chinese investors in PNG's retail sector may be stigmatized by Chinese and PNG state actors, and are lumbered with an outsider status by earlier entrants, the much larger state-backed entrant into the mining sector, MCC, faces different challenges in gaining acceptance.

The Ramu Nickel project, a $\$ 1.4$ billion investment that is operated and majority-owned by the state-owned MCC, ${ }^{55}$ does share the problem of stigmatization within the existing mining sector of PNG. Surveys of local

53 Interview by author, Karkar Island, Madang Province, 20 June 2010.

54 Christine Oelrich, "Ethnic Conflict Flares over Chinese Nickel Mine Pollution," Deutsche Press Agentur, 27 December 2011, available online at http://ramumine.wordpress.com/2011/12/27/ ethnic-conflict-flares-over-chinese-nickel-mine-pollution, last accessed 20 February 2012.

55 MCC owns 85 percent of the venture along with three "silent" partners (Jinchuan Group, Jinlin Ji'en Nickel Industry Corporation, and Jiuquan Iron and Steel Group). The balance is owned by the original holder of the mining lease, Highlands Pacific (8.56\%); the Mineral Resources Development Company (3.94\%), a PNG government agency which holds project equity in trust for local landowners and local-level governments in the mine-affected area; and Mineral Resources Madang Ltd (2.5\%). 
workers at the mine and refinery sites reveal that all workers with previous experience believe the working conditions at the Ramu mine to be inferior to those at other mines in PNG. ${ }^{56}$ Executives of other mining companies, both locally- and foreign-owned, are scathing in their assessments of the willingness of MCC to adapt to PNG. The initial reaction of Ramu Nickel management to such stigmatization was to cut themselves off from other players in the mining sector. As one (white) PNG national who works with the company related: $:^{57}$

We had our first meeting and all the directors [of Ramu Nickel] were there. They expected to see all PNG Nationals. I'm a citizen, and when I walked in, $\mathrm{Mr} \mathrm{X}$ was sitting directly opposite me at the table, and he had this inscrutable Chinese face on, and these jet black eyes staring right at me. I just played it very cool and didn't say anything. They nearly fell off their chairs when I walked in. Because one of the Chinese after that said to me, under no circumstances will we be employing any Australians. They had a real thing about Australians.

Over time, however, MCC management has become more comfortable about hiring expatriates, particularly in the "softer" areas of health, safety and environment (HSE), human resources, or community relations. This division is formalized in another proposed mining project in Madang, the Yandera copper/molybdenum mine. Under current arrangements, the Chinese partner, China Nonferrous, will arrange financing, construction, and off take, while the Australian and PNG partners (Marengo Mining and Petromin) manage other aspects. ${ }^{58}$ However, while MCC has a partnership with Highlands Pacific, a dual-listed PNG and Australian mining company, there is no indication that the Ramu project is likely to become a genuinely internationalized venture, as seen elsewhere, such as China Minmetals ventures in Australia ${ }^{59}$ and South America ${ }^{60}$ All senior directors are Chinese, and their joint venture partners struggle to "get in the room." MCC-managed projects elsewhere follow a similar pattern.

Like the new Chinese retail traders, new Chinese miners have been subjected to negative publicity, ranging from well-researched critiques,$^{61}$ to

56 Graeme Smith, "Nupela Masta: Local and Expatriate Labour in a Chinese-Run Nickel Mine in Papua New Guinea,” Asian Studies Review 37, no. 2 (2013), in press.

57 Interview by author, Madang town, 1 November 2009.

58 Malcolm Roberts, "Yandera Project Update 2011," presented at PNG Chamber of Mines and Petroleum Conference, 30 November 2011, available online at http:/ /www.marengomining.com/ reports/PNGChamberofMinesPresentationPrint.pdf, last accessed 20 February 2012.

59 John Garnaut, "Minmetals a Model for China's Leaders," Sydney Morning Herald, 31 August 2010, http:/ / www.smh.com.au/business/minmetals-a-model-for-chinas-leaders-20100830-147bm.html, last accessed 28 February 2012.

60 Gonzalez-Vicente, "Internationalization of the Chinese State," 406-7.

61 Patrick Matbob, "Ramu Nickel Project Blunders On," Islands Business, available at http:// www.islandsbusiness.com, last accessed 21 February 2012. 
ill-informed polemics. ${ }^{62}$ While an article in The Australian newspaper, entitled "China's Neo-colonial Slavery in PNG," wondered why "the loose coalition of organisations that did, in fact, damn BHP over Ok Tedi and Rio over Bougainville have been ominously silent about Ramu," ${ }^{63}$ evidence suggests precisely the opposite. The project has inspired a popular anti-mining blog that was initially dedicated solely to critiquing it. ${ }^{64}$ Australian-based NGOs such as the Mineral Policy Institute have devoted considerable resources to opposing a mine that is yet to destroy a river system (Ok Tedi), or ignite a civil war (Bougainville). The reaction of the mine management has been to withdraw from engagement. They directly or indirectly (through partners in the provincial or central government) pressure local government officials who show an inclination to provide commentary. Civil society actors, however, are free to provide domestic and foreign media outlets with their assessments. There is no question of who is winning the media battle, even though the mine is proceeding. As the case of Minmetals illustrates, a reactive and inward-looking approach is not inevitable. It seems to partly derive from the corporate culture of MCC.

In its interaction with the Chinese state, there is a sentiment among senior project management that even though the project is backed by a China Exim Bank loan, they have not received enough government support, such as complementary infrastructure investment, ${ }^{65}$ as is seen in some "resources for infrastructure" projects in Africa. Its executive director and Party secretary, Shen Heting (b. 1954), complained that the level of government support MCC had received for its outbound investments was like "one hair of nine oxen" (jiu niu yi mao). ${ }^{66} \mathrm{MCC}$ does not have political clout comparable to State Grid, Sinopec or other large SOEs, ranking as the 31st largest Chinese company according to the Fortune 500 Index ${ }^{67}$ While the directors of SOEs have more political clout than many of the officials in the ministries that are meant to oversee them, ${ }^{68}$ the chairman of MCC, Jing Tianliang (b. 1945), was previously deputy director of the Coal Industry Bureau, and is largely

62 John F.M. Kocsis, "Papua New Guinea's Great Power Conflict," Harvard Political Review, 15 February 2012, available online at http:/ / hpronline.org/world/papua-new-guinea-proxy-for-the-great -powers, last accessed 20 February 2012; Oelrich, "Ethnic Conflict Flares."

63 Rowan Callick, "China's Neo-colonial Slavery in PNG," The Australian, 12 February 2007.

64 Papua New Guinea Mine Watch, available online at http://ramumine.wordpress.com, last accessed 20 February 2012.

65 One exception is a K22 million Chinese government grant to upgrade a $16 \mathrm{~km}$ stretch of the Usino-Yamagi road, which opened in October 2012. Most of the road to the mine site, however, remains a muddy track, often impassable in the wet season.

66 Yan Jiangning, "Zhongye haiwai zhao kuang lu” [MCC Seeks Mineral Wealth Overseas], Caixin, 6 September 2010, available at http:/ / magazine.caixin.com/2010-09-04/100177070.html, last accessed 20 February 2012.

67 Online at http://money.cnn.com/magazines/fortune/global500/2011/countries/China. html, last accessed 28 February 2012.

$\frac{1}{68}$ For a discussion of the appointment of directors to large SOEs, see Erica Downs and Michal Meidan, "Business and Politics: The Oil Executive Reshuffle of 2011," China Security 19 (2011): 3-21. 
distinguished by being one of the oldest SOE leaders. ${ }^{69}$ For the Organization Bureau, the organ in charge of appointing senior Party and government figures, to appoint a middling Party official at the end of his career to represent MCC suggests a decline in influence. Yet MCC, as an offshoot of the Ministry of Metallurgy (yejin bu), still feels a sense of entitlement to strong state backing, which it enjoyed throughout the Maoist period, when steel was taken as "the key link" in the economy. ${ }^{70}$ Proximity to the central and provincial state brought rewards, and a Maoist flavour pervades the corporate culture, with instructions from MCC management conveyed in yellow envelopes marked "documents" (wenjian).

While other Chinese resource companies pay lip service to the central state's concern for "resource security" as a way of extracting concessions, while in practice being driven largely by the profit motive, ${ }^{71}$ MCC's executive director, Shen Heting, believes that he is acting in the interest of the nation in securing resources. Thus MCC should be supported by the state, regardless of whether its overseas ventures are profitable. As he explained, "Central government enterprises that secure mines overseas are in reality securing resources for China ... we can only rely on the support of the central government and our own efforts to avoid them. As long as it is a good resource, we will go for it." In response, an analyst from Northwest Securities noted, "The feeling I get is that they [MCC] will sink their teeth into any mine they come across, without a clear understanding of what exactly they want to develop." 72

The release of US government cables by Wikileaks provided an insight into Shen's thinking, when he briefed a visiting US delegation to Afghanistan on 12 November 2009:

Despite the difficulties MCC faced in Aynak, Shen said the Chinese
government gave the company 'clear instructions' to honor its contract
and keep to the original schedule. At the same time, MCC did not believe
it could ask the Government of China to intervene with the Government
of Afghanistan to request additional security forces. While MCC planned
to train local laborers to work in the mine, it would recruit Chinese
engineers for the jobs requiring university qualifications. Shen said

69 Cheng Li, "China's Midterm Jockeying: Gearing up for 2012. Part 4: Top Leaders of Major State-Owned Enterprises," China Leadership Monitor 34 (2011): 16.

70 David Bachman, Bureaucracy, Economy, and Leadership in China: The Institutional Origins of the Great Leap Forward (Cambridge: Cambridge University Press, 2006).

71 McCarthy, this volume. See also Erica Downs, "Inside China, Inc: China Development Bank's cross-border energy deals," 21 March 2011, available online at http://www.brookings.edu/ papers/2011/0321_china_energy_downs.aspx, last accessed 28 January 2012.

72 Yan, "MCC Seeks Mineral Wealth Overseas." This assertion is supported by a survey of Chinese mining companies, which found that MCC's overseas mining investments were the most disparate in terms of geography and target minerals. Ruben Gonzalez-Vicente, "Mapping Chinese Mining Investment in Latin America: Politics or Market?” China Quarterly 209 (2012), 38. 
existing roads would be sufficient to transport the copper from the mine and that construction of a railway from the mine to the Pakistan port of Gwadar was not economically justified. However, he reiterated that the Chinese government was urging the company to honor its commitments, suggesting that MCC might eventually build some railway.

Then ambassador Jon Huntsman noted, "MCC has never before been so blunt with us about the fact that it is state-owned. Shen's repeated references to state instructions likely were his way of absolving the company of proceeding with what he saw as an economically unsound project." 73

While the introduction to this volume describes how Chinese firms are learning from Japan's experience, in public pronouncements Shen Heting insists that other countries adapt to his investment model. During Prime Minister Julia Gillard's visit to Beijing in 2011, Shen delivered a homily on the need for Australia to change its migration and labour laws to allow for large-scale use of Chinese labour. ${ }^{74}$

Of all three sectors examined in this paper-retail, mining and construction-the Ramu Nickel project would appear to be the most unified actor with the closest links to the state. When MCC does communicate with the press in PNG, this is the impression it conveys. However, closer examination of the project reveals a more complex reality. Due to the emergence of MCC from the Ministry of Metallurgy, the corporation is divided up into a number of provincially based companies, which roughly correspond to the former provincial offices of the ministry. The Kurumbukare mine site is staffed by contractors from MCC 19 and ENFI (Engineering Non-Ferrous Institute) 19, which hail from Chengdu, the capital of Sichuan Province. These contracting companies are brought in for specific tasks (in the case of MCC 19 and ENFI 19 , constructing the mine site). Due to the complexity of work at the Basamuk refinery site, there is a more heterogeneous group of contractors engaged there, with contractors from Tangshan's MCC 22 and ENFI 22, Shanghai's MCC 20 and ENFI 20, and Anshan's (Liaoning Province) 3MCC. Rather than being a singular Chinese work unit, this fragmentation of contractors means that each work site has a distinctive work culture, and a distinct set of local identities, based on shared work histories, cultural preferences and local dialects. Similar balkanization was observed by a Chinese journalism student in Ecuador, who asked, "How can the Ecuadorians understand the Chinese?' A Sinopec manager said with exasperation, 'There are lots of subsidiaries here. Chinese people from different provinces rarely talk to each other.' He

73 US Embassy Beijing, "Chinese firm re-thinks Afghan mining contract after difficulties of the Aynak copper mine project," 10 December 2009, available online at http:/ / www.cablegatesearch.net/ cable.php?id=09BEIJING3295, last accessed 28 February 2012.

74 John Garnaut, "Talks Mark the End of China's Disdainful Arrogance," Sydney Morning Herald, 3 May 2011, http://www.smh.com.au/business/talks-mark-the-end-of-chinas-disdainful-arrogance -20110502-1 e560.html\#ixzz1npicQxSa, accessed online 28 February 2012. 
said the locals wouldn't believe how much Chinese workers love their small cliques." ${ }^{75}$ An engineer explained such divisions were apparent in PNG: ${ }^{76}$

The parent company, it's a large SOE so many of its staff are stuck in the planned economy, always spouting official rhetoric (guanchang lundiao). MCC 19 and ENFI 19 are better. They were the first to change structure, so they have a more market-based approach to project management. MCC 22 [from northern China] at the refinery is different; it's an old enterprise. ${ }^{77}$ When I visited for an inspection, everyone wanted to tell me what to do. But as soon as I pointed out problems, no one wanted to know... Sichuan [home to ENFI 19] is a populous province, where the pressures of subsistence forced people to work, otherwise there's nothing to eat. But the other areas are close to the capital. The closer you are to the emperor, the more you prostrate yourself; it's the traditional way. The [management] spend all their time fighting over spoils, but when it comes to external matters, they ignore issues they should manage, and stick their nose in when it's not needed... thousands of years of official bickering hasn't changed; thousands of years of the feudal society, up to present-day socialism, officials haven't changed.

While in public announcements MCC gives the impression that it is in full control, day-to-day operation, particularly during the construction phase, is in the hands of contractors who are financially independent. This fragmented contracting system, where each contractor is self-regulating and has no longterm involvement, results in a short-term, limited liability approach to project management. It leads to pressure on local and Chinese workers to undertake longer hours to fulfil contracts ahead of time, and conversely to reduce expenditures on wages, safety equipment and accommodation. Many intractable disputes with landowners involve contractors, and if they have already returned to China, prospects of redress are slim.

In a perfect regulatory regime, such pressures would not be a source of tension, but local government in PNG does not have the capacity to enforce its own regulations governing wages, workers' safety or land titling, similar to the situation at other Chinese mining enclaves in Africa. ${ }^{78}$ Other than police, whose incomes are supplemented or paid in full by the mining company ${ }^{79}$ and a single health worker at the Basamuk clinic, the PNG government has no presence at the mine site. The scope for the local state

75 Huang Hongxiang, "Zhongguo liuxuesheng zhishen tanfang yamasun” [A Chinese Student's Solo Trip to the Amazon], Nanfang Zhoumo [Southern Weekend], 17 April 2012, http://www.infzm. com/content/74135, accessed online 18 January 2013.

76 Interview by author, Naru pipeline camp, 7 February 2010.

77 MCC's current executive director, Shen Heting, was originally the director of MCC 22.

78 Dan Haglund, "In It for the Long Term? Governance and Learning among Chinese Investors in Zambia's Copper Sector," The China Quarterly 199 (2009): 641-45.

79 This is not a new (or uncommon) practice in PNG. Sinclair Dinnen, Challenges of Law and Order in a Weak State: Crime and Politics in Papua New Guinea (Honolulu: University of Hawai'i Press, 2001). 
to pressure Ramu Nickel to adopt local norms is thus limited. There are credible actors within the Ramu Nickel project, both Chinese and local, who have encouraged management to borrow and adopt external norms, in order to "get things done" more effectively in PNG. ${ }^{80}$ Many procedures, particularly health and safety, have improved. However, the debate has an instrumentalist tone, and insider proponents, be they "unrealistic" young graduates or "bookworm" managers, are often portrayed as stooges who are too soft on PNG workers. Many leave the project early in frustration. One graduate signed off:

A colleague said that Ramu isn't a cohesive company. I'd add that the only time that we gather together with cohesion is when everyone curses the company and the management. There is a saying, the only people who stay are the incompetent. The leaders' rhetoric is like panning for gold with a big wave; only sand is gathered, gold is left behind. For some, Ramu is a great work unit, because they have no ability to work, and with little fuss they collect what to them are very good wages. For some it becomes hell. Wherever they go, there's a small clique, those insufferably arrogant and irresponsible ones who hold the power. It destroys the work environment. Those who want to develop naturally leave one by one.

\section{The Construction Sector}

While the new Chinese in the mining and retail sectors have limited interaction, the line between mining companies and construction companies need not be too finely drawn. Several emerging construction companies in PNG, such as Oriental Star and PNG SJ, arose from the Ramu Nickel project. In the case of PNG SJ, their name derives from their parent company, MCC 19 (nineteen in mandarin Chinese is shi jiu), and workers still wear their old MCC and ENFI uniforms. The histories of these two construction companies are worth exploring, as they highlight the blurred boundaries that international engagement brings to nominally state-owned companies. Both were registered in PNG less than five years ago. PNG SJ is the locally registered arm of ENFI 19, the main contractor at the Kurumbukare mine site. Their workers and management largely hail from Sichuan Province. The work and management culture is distinct from Oriental Star, which arose from the Shanghai-based MCC 20, responsible for the electrical infrastructure at the Basamuk refinery. There is little love between the two companies, which now compete for construction contracts in Madang and beyond. During the construction phase, both companies acted with considerable autonomy, drawing on their own finances and personnel, and often ignoring the instructions of the management company, leading to conflicts with local landowners and workers. They are still nominally state-owned, but

80 Acharya, "How Ideas Spread," 251. 
(particularly in the case of PNG SJ) local management now enjoys even more autonomy from their head offices, and is developing close links to local businesspeople and politicians. Such links will be crucial in securing a share of a China Exim Bank loan facility, potentially worth $\$ 5$ billion, that was announced during the 2012 elections. While the line between construction and mining companies is blurred, as the following story illustrates, the line between Chinese investors in the construction and retail sectors is definitive in the minds of many Papua New Guineans.

In May 2009, a demonstration organized by an NGO in Port Moresby against Asian migration turned to looting, which soon spread to all major towns around PNG, spilling out onto the streets of Goroka on May 17. The new Chinese in the retail sector were the main target of the riots, ${ }^{81}$ but the mob's attention soon turned from the West Goroka shops to a high-profile Chinese construction project, a student dormitory that was being built by a large workforce recruited by Guangdong Foreign Construction Company (GDFC), with financing later provided by China Exim Bank, one of the maligned "soft loans" to the Pacific. ${ }^{82}$ With news of the approaching crowd, all Chinese workers were locked away in the university auditorium, but the administrators need not have troubled themselves. A large mob of students met the protestors at the gate of the university and chased them away, arguing that the Chinese were building their dormitory. ${ }^{83}$ To my knowledge, this is the first instance of a pro-Chinese riot in the Pacific.

The treatment of Chinese construction companies is in stark contrast to those in the mining and retail sectors. Negative coverage of their activities is largely absent from the press, even though some projects, particularly the dormitories at Vudal University, also constructed by GDFC, have involved shoddy workmanship. Although some of the projects they are involved in are unpopular, community groups and the media have not yet targeted them. That is not to say physical insecurity is absent from their lives; the skeleton construction crew at the University of Goroka was tied up and robbed one Christmas Eve. When staff go into town, they are accompanied by bodyguards, a level of security that goes beyond that provided by MCC.

Their relationship with the Chinese state is less problematic than that faced by investors in the retail and mining sectors. Most construction companies are offshoots of relatively large state-owned companies in China.

81 A riot arising from the inept handling of an accident at the Basamuk refinery plant erupted earlier in May, but this was localized to Basamuk. It was unrelated to the demonstration in Port Moresby, which was organized several weeks beforehand. This did not stop media outlets from connecting the events. Rowan Callick, "Looters shot dead amid chaos of Papua New Guinea's anti-Chinese riots," The Australian, available online at http://www.theaustralian.com.au/news/looters-shot-dead-amid-chaos -of-papua-new-guineas-anti-chinese-riots/story-e6frg6no-1225715006615, last accessed 28 February 2012.

82 Mary Fifita and Fergus Hanson, "China in the Pacific: The New Banker in Town," available online at http:/ / www.lowyinstitute.org/Publication.asp?pid=1546, last accessed 28 February 2012.

83 Interviews with administrators, University of Goroka, 8 and 19 November 2011. 
While there may only be a handful of staff in-country (in the case of GDFC, there are just two staff based in Port Moresby, compared to the scores of directors and managers employed by MCC) lobbying occurs at the provincial and central government levels to bring in funding for projects, either as grants, or as soft loans from "policy banks," in many cases the same banks which have funded infrastructure development within China.

Construction companies such as GDFC, China Overseas Engineering Group (COVEC) and Sinohydro now drive China's aid program, through informal and semi-formal partnerships formed with the formal aid actors, such as the Ministry of Commerce, China Exim Bank and various ministries, who are subject to their lobbying efforts. Lucy Corkin, in an excellent analysis of tensions between China Exim Bank, the Ministry of Commerce and the Ministry of Foreign Affairs, notes that construction companies "push their own agenda ... through Angolan power brokers," but in her diagrams explaining the implementation process for Exim Bank funded projects, the arrows point downwards. ${ }^{84} \mathrm{~A}$ two-way arrow is required.

This is not to imply that all Chinese construction companies can be treated as a homogeneous group. ${ }^{85}$ Size matters. There are power imbalances between different contractors, and at least one instance of a "fake SOE" posing as a reputable Chinese construction company ${ }^{86}$ GFDC managers cheerfully admit they are not in the same league as COVEC in terms of political influence in PNG or China. At the other end of the scale, the local managers of privately owned Huawei, the world's second-largest telecommunications company and beneficiaries of a soft loan to develop the "Integrated Government Information System Network," ${ }^{87}$ demonstrate behaviour in line with the worst clichés of state-owned enterprise arrogance. They are known for appearing unannounced in the offices of PNG Treasury and refusing to leave until their terms are met. ${ }^{88}$

Interactions with the PNG state and local communities are less tense than in the retail and mining sectors. At the local level, the oft-criticized practice of setting up camps separate from the community is welcomed, with many interviewees noting with approval after the completion of projects that, "they kept to themselves." However, the relationship of construction companies towards some parts of the PNG state can be fraught. The Labor Department and the Ministry of Foreign Affairs and Immigration regularly refuse work

84 Lucy Corkin, "Redefining Foreign Policy Impulses toward Africa: The Roles of the MFA, the MOFCOM and China Exim Bank,” Journal of Contemporary China 40, no. 4 (2011), 61-90.

85 While there are a dozen Chinese construction companies registered in PNG, this is not the case throughout the Pacific. Samoa allows just one company, Shanghai Construction Group, to operate. Interview by author, Apia, Samoa, December 2011.

86 Interview by author, Madang and Port Moresby, November 2011.

87 China Daily, "Chinese Telco Giant Huawei to Invest in PNG," 22 April 2009, available online at http://www.chinadaily.com.cn/bizchina/2009-04/22/content_7704439.htm, last accessed 28 February 2012.

88 Interview by author, Port Moresby, November 2011. 
permits and visas to the migrant work forces that these construction companies depend upon to complete their projects. In the case of aid projects, the PNG National Executive Council often grants exemptions from these laws, but delays still occur. While construction companies cultivate personal relationships with local political leaders to increase the chances of their firm being chosen for projects, difficulties occur when projects are too closely tied to individual PNG politicians. In the case of the Pacific Marine Industrial Zone project, closely associated with the former commerce minister, Gabriel Kapris, and the former fisheries minister, Ben Semri, when the politicians fell from grace, their Chinese partners found the project difficult to prosecute.

While the Chinese state is often critiqued for its reluctance to engage in multilateral processes, preferring bilateral engagement, multilateral agencies in PNG have a positive view of Chinese construction companies. Staff at the Asian Development Bank (ADB) and the World Bank praise Chinese contractors for finishing projects on schedule, avoiding cost overruns, and being flexible when project delays are encountered. ${ }^{89}$ Far from being dependent on Exim Bank loans, Chinese construction companies based in PNG have learned to put together professional bids, often with international partners. COVEC is now the leading contractor involved in ADB loan projects in PNG. ${ }^{90}$ In conversations with COVEC representatives, it becomes clear that they have adopted many international norms because they enhance their legitimacy, and can be used to question the legitimacy of others. ${ }^{91}$ There is also evidence of "norm displacement" on the part of their multilateral partners, who tolerate the high proportion of Chinese labour used in these construction projects.

\section{Conclusion}

Although Chinese investors operating in different sectors of the PNG economy face a similar legal and political environment, their capacities to localize and adapt to this environment are radically different. For a variety of reasons, including the relatively small size and flexibility of their local offices, the perception of locals and the local state that their work is well defined and relatively benevolent, and their exposure to a variety of different operating environments, Chinese construction companies are better able to find congruence with local norms than their compatriots in the retail and mining sectors. This is not to say that the other investors will never build congruence with local norms in PNG-the "old" Chinese were once "new" Chinese, after all, or that Chinese construction companies will never be

89 Interviews with author, Port Moresby, November 2011.

90 ADB, “Asian Development Bank \& PNG: Fact Sheet," April 2011, available online at http:// www.adb.org/Documents/Fact_Sheets/PNG.pdf, last accessed 28 February 2012.

Acharya, "How Ideas Spread," 248. 
stigmatized. A researcher from PNG's National Research Institute has blamed the "Look North Policy" for the "culture of corruption in housing." ${ }^{2}$ Port Moresby has some of the least affordable housing in the Pacific.

Yet there is no denying that investors in the mining and retail sectors face greater difficulties in adopting the role of "norm-takers." In the case of the former, language barriers and a strong but inward-looking enterprise culture hinder their ability to adapt, particularly at the middle-management level. While ten years of collective leadership under $\mathrm{Hu}$ Jintao might condition us to expect SOE managers to behave in a similar manner, the Ramu Nickel project demonstrates that extremes of centralized and decentralized decision making can be observed within the one state-owned enterprise. Shen Heting, MCC's executive director, has extraordinary influence over the "big" decisions of when and where to invest. These decisions are based on a complex mixture of commercial, political and personal objectives. Profit maximization is not the sole concern; non-profit-related commercial objectives, such as winning symbolic victories over corporate rivals or increasing market share, appear to predominate. The strategic designs of the Chinese central government, or concerns about local norms in the host country, seem to play a limited role in the decision-making process. At the other extreme, day-to-day operations, particularly during the construction phase, are highly decentralized, with individual contractors concerned with profit maximization, achieved by finishing their part of the project as rapidly and cheaply as possible. Adapting to local norms is of little concern, leaving the project management company to deal with the stigmatization that is accrued.

For the retail investors from Fuqing, a strong sense of cultural identity as "outsiders" in both China and PNG, dovetailed with a lack of acceptance by the PNG state and the existing Chinese community, limits their inclination to adjust their business practices to be more in line with local norms. While there are exceptions, particularly among well-established traders who have managed to diversify into wholesale business or other sectors of the economy, their relatively short time horizon for investment furthers their stigmatization in the eyes of local communities. On a micro scale, evidence of their adaptability abounds: their grasp of Tok Pisin, and understanding of local culture is far superior to their compatriots in the mining and construction sectors. On a macro scale, their aggregate economic impact outstrips Chinese investment in mining and construction. Unfortunately, in social terms, their very ubiquity fixes their social identity as "discredited people" ${ }^{93}$ in PNG, more physically vulnerable than their compatriots to the caprice of the local state, and unable to find acceptance within the local society.

University of Sydney, Sydney, Australia, January 2013

92 Melanie Vari, "Corruption in Housing," Post Courier, 24 October 2012, available online at http://www.postcourier.com.pg/20121024/southernpost01.htm, last accessed 26 October 2012.

Goffman, Stigma, 4-34. 